\title{
Volcanic systems in the San Pedro-Ceboruco graben (Nayarit, Mexico) in the light of new K-Ar geochronological data
}

\author{
C. M. Petrone, ${ }^{1,2} *$ T. Tagami, ${ }^{2}$ L. Francalanci, ${ }^{1,3}$ A. Matsumura ${ }^{2}$ and M. Sudo ${ }^{4}$ \\ ${ }^{1}$ Dipartimento di Scienze della Terra, Università degli Studi di Firenze, Via La Pira, 4, Firenze, I-50121, Italy \\ ${ }^{2}$ Division of Earth and Planetary Sciences, Graduate School of Science, Kyoto University, \\ Kyoto 606-8502, Japan \\ ${ }^{3}$ C.N.R., C.S.M.G.A., Via La Pira, 4, Firenze, I-50121, Italy \\ ${ }^{4}$ Sakurajima Volcano Research Center, Disaster Prevention Research Institute, Kyoto University, \\ Uji, Kyoto 611-0011, Japan
}

(Received December 22, 1999; Accepted December 28, 2000)

\begin{abstract}
Six new K-Ar ages were determined for three of four volcanic systems that constitute the San PedroCeboruco graben of western Mexico, in order to give constraints on stratigraphic relationships and problems of magma genesis in an area characterized by the coexistence of magmas with different petrologic affinities (calc-alkaline and intra-plate type). Previous age determinations are scarse for this region. Samples were dated using the unspiked K-Ar sensitivity method with a mass-fractionation correction procedure. Our new data, along with those in literature, suggest that volcanism started at $\sim 2.5 \mathrm{Ma}$ in the southwest part of the graben. Between $\sim 2.3$ Ma to $\sim 0.1$ Ma volcanic activity continued in the central part of the graben and starting from $\sim 0.5 \mathrm{Ma}$, volcanism also extended to the northern part. This northward shifting of the volcanic activity with time occurred along NW-SE trending lines which coincide with the main regional fault systems, and could be linked to the resumption of convergence after a period of near-cessation. The major phase of the magmatic activity is younger than $0.5 \mathrm{Ma}$, but the presence of volcanic activity strictly differentiated in magmatic affinities (orogenic and intra-plate), started earlier, around 1.1 $\mathrm{Ma}$ and is linked to sub-slab melts flowing in the mantle wedge. The age obtained on the dome complex (San Pedro-Cerro Grande Volcanic Complex) along with literature data suggest that the caldera collapse event occurred before $\sim 1.1 \mathrm{Ma}$ and was followed by intracaldera and pericaldera activities. After $\sim 0.6 \mathrm{Ma}$, subsidence and consequent reactivation of the eastern caldera rim, can have determined the cutting of some pericaldera domes.
\end{abstract}

\section{INTRODUCTION}

The San Pedro-Ceboruco (SPC) graben is located in western Mexico and started to develop during the initial rifting of the southern Gulf of California (Ferrari, 1995). It is part of the wider northwest-southeast trending of Tepic-Zacoalco rift, which forms a triple junction near Guadalajara along with the north-south Colima rift and the eastwest Chapala rift (Allan, 1986) (Fig. 1). The volcanism in the SPC graben is part of the TransMexican Volcanic Belt, the active volcanic arc linked to the subduction of Rivera and Cocos plates beneath North America plate (Fig. 1). At least four different volcanic systems in the SPC graben are recognized (Fig. 2): 1) alignments of monogenetic volcanic centers (cinder cones and domes) located along the northern and southern border of the graben (northern and southern volcanic chains); 2) a silicic volcanic complex (San Pedro-Cerro Grande Volcanic Complex; SCVC), located in the central part of the graben, and constituted by several domes, a few volcanic cones, several thin lava flows (Amado Nervo flows) and

*Corresponding author (e-mail: petrone@steno.geo.unifi.it) 


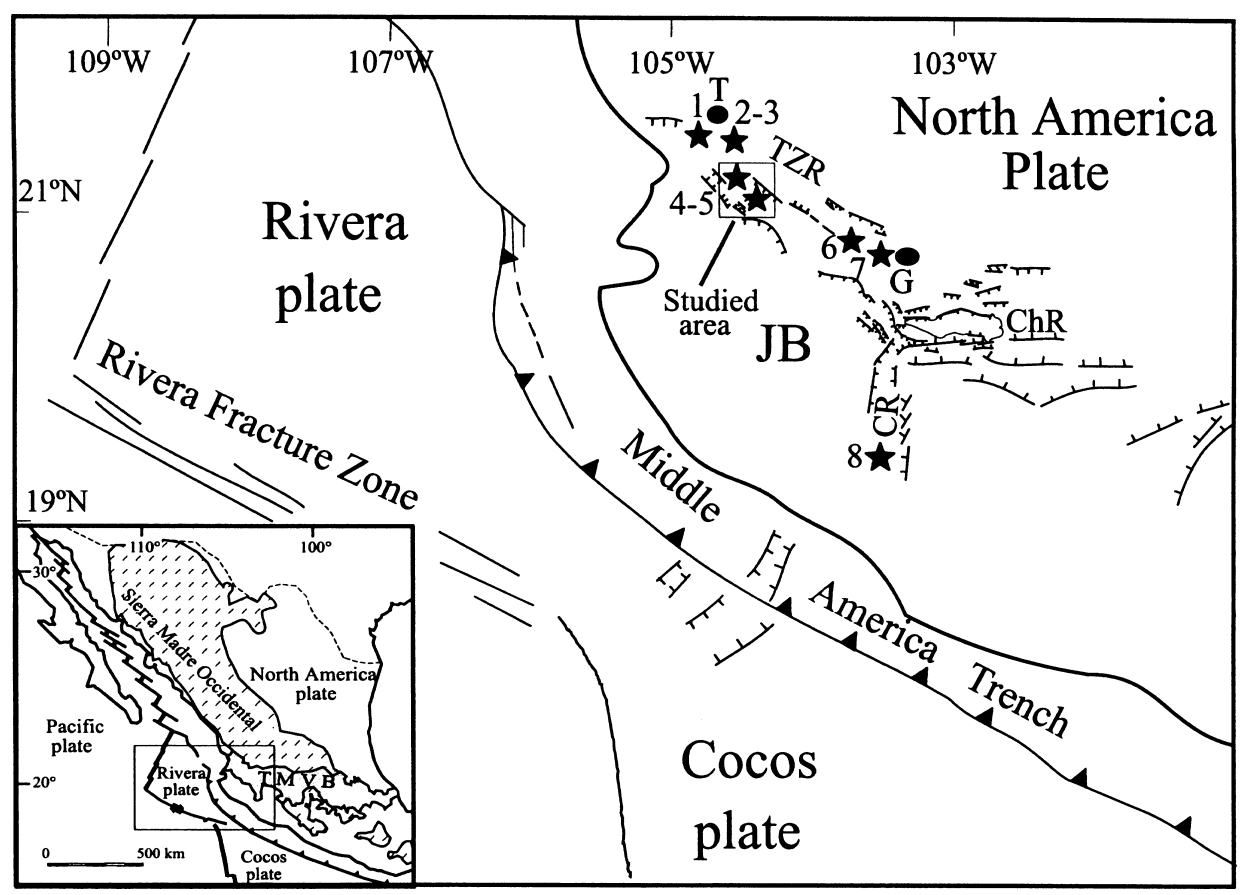

Fig. 1. Schematic geodynamic map of western Mexico. Sketch map of Mexico is shown in the inset. TMVB: TransMexican Volcanic Belt; TZR: Tepic-Zacoalco rift; ChR: Chapala rift; CR: Colima rift; JB: Jalisco block; G: Guadalajara city; T: Tepic town. Stars indicate major stratovolcanoes of the Trans-Mexican Volcanic Belt: 1 San Juan; 2 Las Navajas; 3 Sanganguey; 4 Tepetiltic; 5 Ceboruco; 6 Tequila; 7 Sierra La Primavera; 8 Colima. The location of the studied area is also shown (modified from Rosas-Elguera et al., 1996).

a burial caldera; 3 ) the polygenetic stratovolcano Tepetiltic; 4) the polygenetic stratovolcano Ceboruco. Tepetiltic and Ceboruco are located on the northern border of the graben along with the northern volcanic chain.

Magmatism in the SPC graben is characterized by the coexistence of two different petrologic affinities: subduction-related and intra-plate (Petrone, 1998). Typical calc-alkaline lavas were erupted from the volcanic systems of Tepetiltic (57.1-69.9 $\mathrm{SiO}_{2}$ wt\%), Ceboruco (58.5-69.5 $\mathrm{SiO}_{2}$ $\mathrm{wt} \%)$ and SCVC (61.1-73.0 $\left.\mathrm{SiO}_{2} \mathrm{wt} \%\right)$. Amado Nervo flows, however, show a Na-alkaline composition with 49.8 to $54.7 \mathrm{SiO}_{2} \mathrm{wt} \%$ and an intraplate signature. The northern chain (51.0-70.8 $\mathrm{SiO}_{2} \mathrm{wt} \%$ ) is characterized by the coexistence of calc-alkaline and mildly Na-alkaline magmatism, whereas, the southern chain $\left(51.3-63.9 \mathrm{SiO}_{2} \mathrm{wt} \%\right)$ is made of calc-alkaline lavas with subductionrelated signature and characterized by variable large ion lithophile elements to high field strength elements ratios (Petrone, 1998).

Two main phases in the SCVC volcanic activity are separated by a caldera collapse event. Both phases were mainly characterized by several domes and a few volcanic cones. The pre-caldera phase started at around $2.3 \pm 0.5 \mathrm{Ma}$ (Gastil et al., 1979; all data are K-Ar ages and errors indicate $1 \sigma$ ) with the extrusion of Cerro Las Tetillas dome and ended with the caldera collapse event whose age is still unknown, also considering the recent geochronological data reported by Ferrari et al. (2000a). Indeed, they find an age of $1.1 \pm 0.3 \mathrm{Ma}$ for the peri-caldera Amado Nervo flows (Fig. 2), which partially cover the caldera rim. On the other hand, they also report an age of $0.61 \pm 0.10 \mathrm{Ma}$ on one rock cut by the caldera rim and located at the base of Cerro Lobos, and ages of $0.79 \pm 0.16$ Ma and $0.85 \pm 0.19$ Ma for two intracaldera domes (Fig. 2). The activity ended at $\sim 0.1 \mathrm{Ma}$ with the 




Fig. 2. Schematic geologic map of the four volcanic systems constituting the San Pedro-Ceboruco graben.

extrusion of a dome (Los Ocotes) located along the caldera rim.

The age of Ceboruco volcanic activity is relatively well known. Indeed, it is the only active volcano in the area. The beginning of its activity was around $0.37 \pm 0.20 \mathrm{Ma}$ (Ferrari et al., 1997) and the most recent eruption took place in 1870 A.D. (Nelson, 1980). A caldera collapse event occurred around 1000 A.D. (Nelson, 1980).

No previous geochronological data are available for the northern and southern volcanic chains. Stratigraphic relationships indicate that the former is younger than the latter. Indeed, some of the cinder cones and domes of the southern chain are partially covered by the $1.1 \mathrm{Ma}$ Amado Nervo flows, whereas some of the northern chain cinder cones and domes lie on Ceboruco flanks suggesting an age younger than or around 0.37 Ma. Moreover, southern chain is made up by more roundish and heavily vegetated cinder cones and domes suggesting higher alteration degree probably due to the older age. On the basis of stratigraphic relationships and morphological evidence, southern volcanic chain seems to be almost contemporary with the SCVC pre-caldera volcanic activity. In contrast, few constraints exist about the exact age of the northern chain and it is very difficult to establish the beginning and length of the monogenetic volcanic activity. One datum could be represented by volcanic cones and domes located on the Ceboruco flanks which follow the starting activity of Ceboruco ( 0.37 Ma; Ferrari et al., 1997). Finally, no geochronological data exists for Tepetiltic volcano and the only geologic constraint is given by the $0.1 \pm 0.01 \mathrm{Ma}$ (Ferrari et al., 2000a) of Cerro Los Ocotes, that partially covers its southern flank.

In this picture, it is very difficult to reconstruct stratigraphic relationships of the SPC volcanic systems. This deals not only with the local problem of a better reconstruction of volcanic activity of the area, but with the more general problem of magma genesis in an area where extension is superimposed to active subduction and where magmas with different petrologic affinities (subduction-related and intra-plate) coexist in a narrow area and maybe in a brief time. In this paper we present new geochronological data of the area, in order to clarify the previous problems. 


\section{SAMPLE SELECTION}

K-Ar geochronological data were performed on six selected samples from the SPC volcanic systems. Chemical compositions are given in Table 1 . All the samples chosen are mostly without voids and characterized by a low phenocryst content and no vitrophyric groundmasses. Most of the sample is unaltered with the loss on ignition values (LOI) lesser than 1\%, only one sample (SPC 127 ) has a higher LOI value (1.5\%).

Three samples of the northern chain were analyzed. On the basis of geochemical data it is possible to recognize two chemically distinct series that are characterized by different petrologic affinities. The High-Ti (HTi) (2.2-0.15 $\mathrm{TiO}_{2} \mathrm{wt} \%$ and 52.0-70.8 $\mathrm{SiO}_{2} \mathrm{wt} \%$ ) series shows a mildly Na-alkaline signature, whereas the Low-Ti (LTi) series $\left(1.6-0.8 \mathrm{TiO}_{2} \mathrm{wt} \%\right.$ and 51.0-58.1 $\mathrm{SiO}_{2}$ $\mathrm{wt} \%$ ) is calc-alkaline in composition (Petrone, 1998). There are no differences in the spatial distribution of these two series (Fig. 2). Time relationships between the HTi and LTi series were unknown and this adds further complexity to the stratigraphic reconstruction and to the understanding of magma genesis. Sample SPC 110 from the
HTi series and samples SPC 1 and SPC 50 from the LTi series were analyzed in order to estimate the temporal variations in magmatism along the northern monogenetic alignment. SPC 1 is located in the southeast end of the alignment, whereas the other two samples are located toward the opposite end. They are all basaltic andesites in composition (Table 1). For the southern chain the andesite SPC 26 was analyzed. All of these rocks are characterized by a porphyritic seriate texture with a variable porphyritic index (5-20 vol.\%). Phenocrysts and microphenocrysts are in order of abundance, plagioclase, olivine and orthopyroxene. Rare microphenocrysts of opaque mineral are also present.

In order to date the Tepetiltic volcanic activity, the andesite SPC 75 (Table 1) was chosen from the base of the caldera wall, considering that it could represent one of the oldest exposed lava flows. This rock is porphyritic (20 vol.\%) with phenocrysts and microphenocrysts of plagioclase and olivine. Opaque minerals are only found as microphenocrysts.

In order to constrain the age of SCVC caldera collapse, the rhyolite SPC 127 from Cerro Lobos (Table 1) dome was dated. This dome is cut by

Table 1. Major element (wt\%) analyses of the six samples dated in this work

\begin{tabular}{|c|c|c|c|c|c|c|}
\hline $\begin{array}{l}\text { Sample } \\
\text { Group } \\
\text { Sub-group } \\
\text { Type }\end{array}$ & $\begin{array}{c}\text { SPC } 1 \\
\text { Northern chain } \\
\text { LTi } \\
\text { Basaltic andesite }\end{array}$ & $\begin{array}{c}\text { SPC } 50 \\
\text { Northern chain } \\
\text { LTi } \\
\text { Basaltic andesite }\end{array}$ & $\begin{array}{c}\text { SPC } 110 \\
\text { Northern chain } \\
\text { HTi } \\
\text { Basaltic andesite }\end{array}$ & $\begin{array}{c}\text { SPC } 26 \\
\text { Southern chain } \\
\text { Andesite }\end{array}$ & $\begin{array}{c}\text { SPC 75 } \\
\text { Tepetiltic } \\
\text { Pre-caldera } \\
\text { Andesite }\end{array}$ & $\begin{array}{l}\text { SPC } 127 \\
\text { SCVC } \\
\text { Pre-caldera } \\
\text { Rhyolite }\end{array}$ \\
\hline $\mathrm{SiO}_{2}$ & 56.37 & 54.27 & 56.68 & 58.41 & 58.42 & 71.64 \\
\hline $\mathrm{TiO}_{2}$ & 0.92 & 1.09 & 1.33 & 1.03 & 0.86 & 0.27 \\
\hline $\mathrm{Al}_{2} \mathrm{O}_{3}$ & 18.52 & 18.96 & 17.66 & 17.18 & 18.08 & 14.41 \\
\hline $\mathrm{Fe}_{2} \mathrm{O}_{3}$ & 2.67 & 2.69 & 2.40 & 2.24 & 2.42 & 1.12 \\
\hline $\mathrm{FeO}$ & 3.96 & 4.44 & 5.44 & 4.20 & 3.68 & 0.60 \\
\hline $\mathrm{MnO}$ & 0.12 & 0.12 & 0.15 & 0.11 & 0.10 & 0.07 \\
\hline $\mathrm{MgO}$ & 4.00 & 4.28 & 3.03 & 3.55 & 3.55 & 0.49 \\
\hline $\mathrm{CaO}$ & 7.17 & 7.69 & 6.09 & 6.38 & 6.83 & 1.92 \\
\hline $\mathrm{Na}_{2} \mathrm{O}$ & 3.74 & 4.51 & 4.50 & 3.69 & 4.16 & 3.98 \\
\hline $\mathrm{K}_{2} \mathrm{O}$ & 1.57 & 1.21 & 1.62 & 2.01 & 1.32 & 3.91 \\
\hline $\mathrm{P}_{2} \mathrm{O}_{5}$ & 0.22 & 0.23 & 0.42 & 0.24 & 0.12 & 0.06 \\
\hline LOI & 0.75 & 0.51 & 0.69 & 0.96 & 0.45 & 1.53 \\
\hline
\end{tabular}

SCVC: San Pedro-Cerro Grande Volcanic Complex; LOI: loss on ignition.

Major elements where determined by XRF and traditional wet chemical methods $\left(\mathrm{MgO}, \mathrm{FeO}, \mathrm{Na}_{2} \mathrm{O}\right.$ and LOI) following the method of Franzini et al. (1972). 
the caldera rim (Fig. 2; see also Fig. 5b) and its age may represent the lower limit for the age of the caldera collapse. SPC 127 is characterized by hypocrystalline-porphyritic texture (porphyritic index: 20-25 vol.\%) with phenocrysts of plagioclase, horneblende and phlogopite.

\section{Analytical Procedures}

For each analysis, $80-100 \mathrm{~g}$ of fresh rock were crushed and sieved to $0.25-0.50 \mathrm{~mm}$ in diameter. The sieved samples were washed with distilled water in an ultrasonic cleaner to remove fine grains. All phenocrysts were removed from sieved samples by a Frantz isodynamic separator in order to avoid possible contamination with excess ${ }^{40} \mathrm{Ar}$ that could be contained in the phenocrysts (Dalrymple and Lanphere, 1969; Takaoka, 1989). Aliquots for potassium analyses were pulverized by an agate mortar.

$\mathrm{K}_{2} \mathrm{O}$ and ${ }^{40} \mathrm{Ar}$ analyses were performed at Kyoto University (Japan) geochronology laboratory. $\mathrm{K}_{2} \mathrm{O}$ contents were determined by flame emission photometry method (Matsumoto, 1989) with a precision of $1 \%$. Duplicate analyses were made for each sample and the average values were used for the K-Ar age calculation. Radiogenic ${ }^{40} \mathrm{Ar}$ contents were determined with a VG 3600 Isotech mass spectrometer using the unspiked sensitivity method with a mass-fractionation correction procedure (Itaya and Nagao, 1988; Takaoka et al., 1989; Matsumoto et al., 1989; Matsumoto and Kobayashi, 1995). Detailed analytical procedures and system descriptions are discussed by Sudo et al. (1996) and Matsumoto et al. (1989). Briefly, in the K-Ar sensitivity method, the signal intensity of ${ }^{40} \mathrm{Ar}$ in the unknown sample is compared with that of a standard air sample analyzed in the same day, assuming that: 1) the sensitivity is the same between unknown sample and standard air; 2) there is a linear relationship of the sensitivity between the signal intensity and volume of Ar (Sudo et al., 1996). The calibration of the system was performed as stated by Sudo et al. (1996) using the internal mineral standard of the Kyoto University Sori 93 with $25.0 \pm 0.2 \mathrm{~cm}^{3} \mathrm{STP} / \mathrm{g}$ radiogenic ${ }^{40} \mathrm{Ar}$ concentration (Sudo et al., 1998). Duplicate analyses of ${ }^{40} \mathrm{Ar}$ radiogenic contents were performed for each samples.

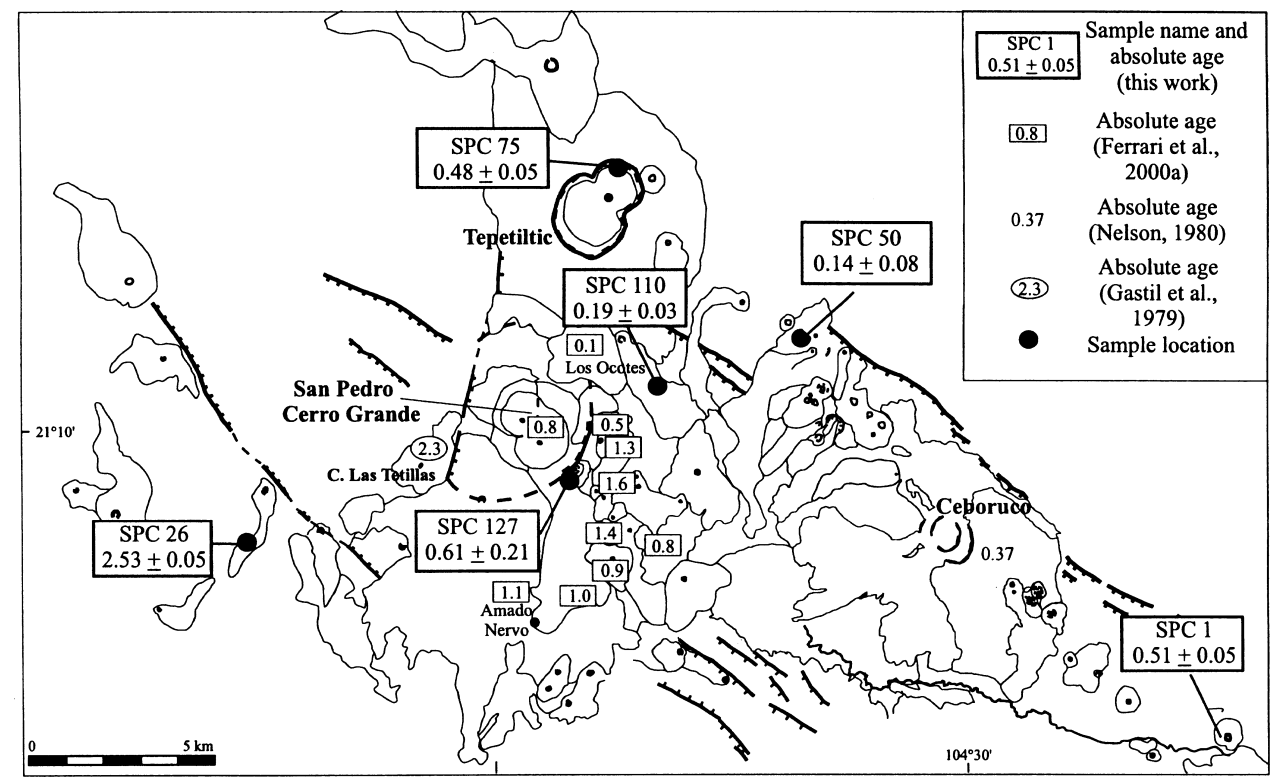

Fig. 3. Schematic map of the San Pedro-Ceboruco graben with K-Ar ages determined in this study. Those reported in literature are also shown. Other symbols are same as in Fig. 2. 


\section{RESULTS AND INTERPRETATIONS}

Analytical results

Analytical results of $\mathrm{K}-\mathrm{Ar}$ ages are given in Table 2. Duplicate analyses of $\mathrm{K}_{2} \mathrm{O}$ contents consistently agree to the estimated analytical uncertainty within $1 \%$ and, thus, mean values were used for each sample. The duplicate analyses of radiogenic ${ }^{40} \mathrm{Ar}$ generally agree within error.

The ages of the northern volcanic chain lavas (SPC 1, SPC 50 and SPC 110) span between $\sim 0.51$ to $\sim 0.14 \mathrm{Ma}$ (Fig. 3 and Table 2). SPC 1 is significantly older than the other two samples with a weighted mean age of $0.51 \pm 0.05 \mathrm{Ma}$. Calculated weighted mean ages for SPC 50 and SPC 110 are identical within error $(0.14 \pm 0.08 \mathrm{Ma}$ and $0.19 \pm$ $0.03 \mathrm{Ma}$, respectively).

Duplicate analyses for the sample from the southern volcanic chain (SPC 26) are in good agreement with relatively low atmospheric ${ }^{40} \mathrm{Ar}$ contamination, giving a well-determined weighted mean age of $2.53 \pm 0.05 \mathrm{Ma}$. The Tepetiltic volcano lava flow (SPC 75) yields a weighted mean age of $0.48 \pm 0.02$ Ma. Duplicate K-Ar data on this sample show slight differences in age at the $1 \sigma$ uncertainty level, by reflecting the relatively low uncertainties $(\sim 6-7 \%)$ for each analysis, although they agree at the $2 \sigma$ level.

Duplicate analyses for the sample from Cerro Lobos dome (SPC 127) are indistiguishable from each other at $1 \sigma$ uncertainty level, with rather high atmospheric ${ }^{40} \mathrm{Ar}$ contamination. This gives a less precise weighted mean age of $0.6 \pm 0.2 \mathrm{Ma}$ (Table $2)$. The greater amount of atmospheric ${ }^{40} \mathrm{Ar}$ contamination in this sample (see " ${ }^{40} \mathrm{Ar}$ atm" and "40 Ar rad" values in Table 2) is probably due to a major contents of vacuoles (around 10\%) in this sample compared to the other samples. The presence of vacuoles may contribute to trap atmospheric ${ }^{40} \mathrm{Ar}$ giving the high atmospheric contamination found in this sample.

\section{Geological inferences}

The calculated ages for LTi series of northern volcanic chain are $\sim 0.51 \mathrm{Ma}$ and $\sim 0.14 \mathrm{Ma}$ whereas the age for HTi series is $\sim 0.19 \mathrm{Ma}$ (Fig.
3). These data confirm that monogenetic volcanic activity of northern chain is young in age and that the volcanism of the two different series of the northern chain might overlap with each other in time. Taking in account the error on the ages (Table 2), we can not rule out that the actual age of SPC 110 (HTi) is younger than SPC 50 (LTi), eventually suggesting that LTi volcanic activity could be older than that of HTi. On the other hand, considering the upper limit ages for both samples, SPC 50 appears younger than SPC 110, eventually suggesting that LTi volcanic activity also lasted longer than that of HTi. Thus, on the basis of these three data it is very difficult to say something more precise regarding time relationships between HTi and LTi series. Anyhow, these data suggest that the volcanic activity of northern chain is almost contemporary with that of stratovolcanoes as indicated by geological evidence. The northern volcanic chain continues northwestward in the Sanganguey area (Fig. 1) where NW-SE alignments of cinder cones are also present. Their volcanic activity started less than $\sim 0.3 \mathrm{Ma}$ ago and ended around $1000 \mathrm{y}$ ago (Nelson and Carmichael, 1984). Thus, it appears that monogenetic volcanism lasted longer in this area compared to SPC graben.

Tepetiltic volcanic activity took place at $\sim 0.48$ $\mathrm{Ma}$, which is in the range of activity of the northern volcanic chain (i.e., $\sim 0.51$ to $\sim 0.14 \mathrm{Ma}$ ) and the final period of SCVC (ending $\sim 0.1 \mathrm{Ma}$ ). Tepetiltic and Ceboruco are among the oldest stratovolcanoes in the Tepic-Zacoalco rift. Sanganguey starting activity is not well constrained but lavas flows erupted in its initial stages of activity cover an ash flow, outpoured from Las Navajas volcano, that was dated at $0.2 \pm 0.1 \mathrm{Ma}$ (Nelson and Livieres, 1986) (Fig. 1). Thus, according to Nelson and Livieres (1986), Sanganguey is younger than this age. The age of the starting activity at Tequila is poorly constrained, but Wallace and Carmichael (1994) stated that it must have postdated $0.46 \mathrm{Ma}$ (no error is reported in literature for this data) and thus, could be in the range of Tepetiltic and Ceboruco starting activity. On the other hand, the youngest vol- 
canoes in the Tepic-Zacoalco rift are San Juan $(>0.03 \pm 0.002 \mathrm{Ma}$; Luhr, 2000) and La Primavera ( 0.14 $\pm 0.004 \mathrm{Ma}$; Mahood and Drake, 1982) located at NW and SE extremes of the rift respectively (Fig. 1).

A K-Ar age of $2.53 \pm 0.05 \mathrm{Ma}$ for southern volcanic chain (SPC 26) confirms that this volcanic activity is older than that of the northern volcanic chain. It also demonstrates that the southern volcanic chain is almost contemporary with the starting activity of SCVC, which coincides with the extrusion of the oldest known dome, the Cerro Las Tetillas, whose age is of $2.3 \pm 0.5 \mathrm{Ma}$ (Gastil et al., 1979) (Figs. 3 and 4).

On the basis of our determined age, the caldera collapse event of the SCVC could be younger than $\sim 0.6$ Ma because the sample SPC 127 gave a weighted mean age of $0.6 \pm 0.2 \mathrm{Ma}$ and it was collected from the base of Cerro Lobos dome cut by the SCVC caldera (Figs. 3 and 5b). This age coincides with that of $0.61 \pm 0.10 \mathrm{Ma}$ measured by Ferrari et al. (2000a) on a rock located at the bottom of Cerro Lobos itself, but does not match with the age of $1.1 \pm 0.3 \mathrm{Ma}$ (Ferrari et al., 2000a)

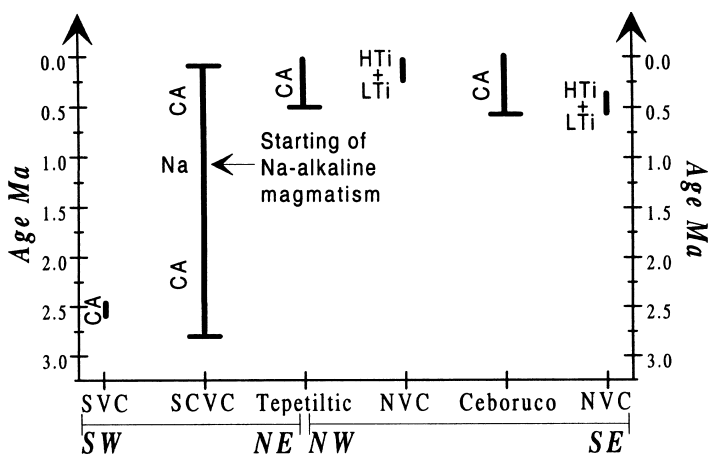

Fig. 4. Stratigraphic relationships between volcanic systems in the San Pedro-Ceboruco graben. Horizzontal bar: starting and ending age of volcanism. Vertical bar: length of volcanic activity based only on available data. SVC: southern volcanic chain; SCVC: San Pedro-Cerro Grande Volcanic Complex; NVC: northern volcanic chain; CA: calc-alkaline magmatism; Na: Na-alkaline magmatism; HTi: HTi series (mildly Na-alkaline magmatism); LTi: LTi series (mildly calc-alkaline magmatism). Data are taken from this study, Gastil et al. (1979) and Ferrari et al. (2000a). of the pericaldera Amado Nervo flows and the ages of two intracaldera domes $(0.79 \pm 0.16 \mathrm{Ma}$ and $0.85 \pm 0.19 \mathrm{Ma}$, Ferrari et al., 2000a) (Figs. 3 and $5 \mathrm{a})$. Thus, an age around $0.8 \mathrm{Ma}$ seems to be the only likely age for a single caldera collapse event which should be nearly coeval with the intracaldera and pericaldera activity (Fig. 5a). Nevertheless, this age is obtained by the overlapping of the two extreme error values of Amado Nervo flows (pericaldera) and Cerro Lobos dome (pre-caldera) (Fig. 5a), implying the exclusion of the literature data on Cerro Lobos $(0.61 \pm 0.10$ $\mathrm{Ma}$ ) that having a low error disagrees with the age of $0.8 \mathrm{Ma}$. Furthermore, the coincidence of the geochronological data on Cerro Lobos dome (Fig. 5a), strongly suggests that $0.6 \mathrm{Ma}$ represents the real age for this dome. According to the latter considerations, we propose an alternative and more probable hypothesis for the age and evolution of the SCVC caldera (Figs. 5a and b). The presence of the pericaldera Amado Nervo flows points to a caldera collapse occurred before $\sim 1.1 \mathrm{Ma}$. This was followed by the emplacement of three huge intracaldera domes and some pericaldera domes as could be the Cerro Lobos. After $\sim 0.6 \mathrm{Ma}$, a process of caldera subsidence, probably determined by the extrusion of the intra- and pericaldera domes, can have reactivated the old caldera rim. This hypothesis, therefore, suggests that the presently exposed cut of Cerro Lobos is younger than the caldera collapse event and Cerro Lobos itself could be a post-caldera dome.

Overall, it is possible to delineate a shift in the location of volcanic activity with time (Fig. 4). Monogenetic volcanism started at $\sim 2.5 \mathrm{Ma}$ along the southern border of the graben. Starting from $~ 2.3$ Ma volcanic activity was mainly characterized by dome extrusion and became localized in the central part of the graben with the emplacement of the oldest rocks of SCVC. At $\sim 0.5 \mathrm{Ma}$, volcanism also migrates along the northern border of the graben with the emplacement of the monogenetic centres of northern volcanic chain and with the formation of the two stratovolcanoes (Tepetiltic and Ceboruco). Most of the shift of volcanic activity took place along NW-SE sub- 
parallel lines, starting from the southern border of the graben. This direction coincides with that of the main regional faults (Ferrari and RosasElguera, 2000) confirming a strict link between magmatism and extensional tectonics. Convergence rate between Rivera and North America plates resumed at around 1.0 Ma (DeMets and Traylen, 2000) after a period of decreasing that
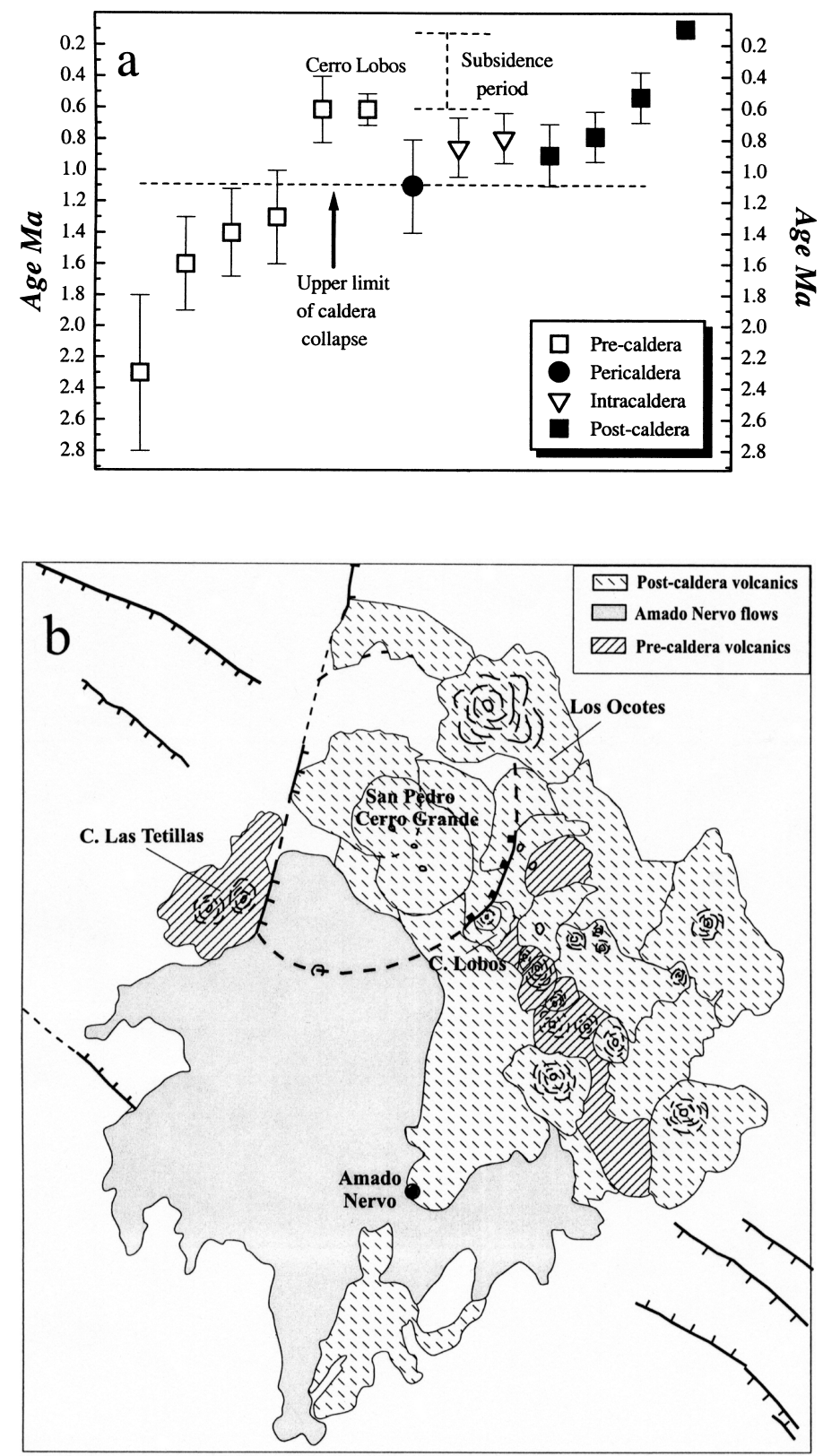

Fig. 5. a) Geochronological ages with their errors for San Pedro-Cerro Grande Volcanic Complex as emerged from this study and previuos works (Gastil et al., 1979; Ferrari et al., 2000a). The hypothesis for the age and evolution of the caldera collapse is shown. For detailed explanations see text; b) Schematic geologic map of the San Pedro-Cerro Grande Volcanic Complex as emerged from this study. Other symbols are same as in Fig. 2. 
started at $~ 3.6 \mathrm{Ma}$ (DeMets and Traylen, 2000) and was followed by a near-cessation of trenchnormal convergence between 2.6-1.0 Ma (DeMets and Traylen, 2000). During this period of cessation of convergence a slab sinking along with a shifting toward the trench of the volcanic arc front occurred (Ferrari et al., 2000b). Volcanic activity along the southern border and in the central part of the graben took place during the period of nearcessation of convergence. Whereas, the shifting of volcanic activity along the northern border of the graben could be linked to the resumption of convergence that, as stated by DeMets and Traylen (2000), was also associated with an increase in the Pacific-Rivera spreading rate.

The major phase of the volcanic activity started less than $\sim 0.5 \mathrm{Ma}$ in coincidence with the emission of volcanics along the norther border of the graben. In fact, the volume of the two stratovolcanoes amount to $100 \mathrm{~km}^{3}$, whereas the volume for the other volcanics is estimated around $14.5 \mathrm{~km}^{3}$ for Amado Nervo flows and $36 \mathrm{~km}^{3}$ for all the other volcanics from monogenetic centers (Ferrari et al., 2000b). Furthermore, our data confirm that different kinds of magmatism (calc-alkaline and Na-alkaline; Petrone, 1998) coexist in a short period of time of $\sim 1 \mathrm{~m}$.y. and that calcalkaline magmas initially precede the Na-alkaline ones. Coexistence of Na-alkaline and calc-alkaline magmatism is also found NNW of SPC graben (Nelson and Carmichael, 1984; Nelson and Livieres, 1986; Nelson and Hegre, 1990; Righter et al., 1995; Ferrari et al., 2000b). In detail, the 1 Ma old Jumatan lava flow (Righter et al., 1995; Ferrari et al., 2000b) near Tepic and almost all cinder cones ( $<0.3 \mathrm{Ma}$, Nelson and Carmichael, 1984 ) around Sangaguey volcano are Na-alkaline (Nelson and Livieres, 1986), whereas Las Navajas volcano is made up by trachyte and peralkaline rhyolite (Nelson and Hegre, 1990) (Fig. 1). Even if calc-alkaline magmatism is dominant in volume, the presence of Na-alkaline magmatism seems, therefore, to be important, especially in the last 1 m.y. in the northwestern edge of the TepicZacoalco rift. As suggested by Ferrari et al. (2000c) the presence of Na-alkaline magmatism along with the calc-alkaline one could be determined by sub-slab asthenosphere melts flowing through the fractured Rivera plate and interacting with the subduction-metasomatized mantle wedge. The break-off of Rivera plate is due to the extensional tectonics linked to the opening of the Gulf of California. Thus, our data along with the literature ones confirm that the strict coexistence of calc-alkaline and Na-alkaline magmas in the SPC graben starts around 1.1 Ma and spans in the same range of age of the NNW occurrences in the Sanganguey and Tepic areas, suggesting that the magmatism in this area could be explained in the same way. In detail, sub-slab astenosphere could have interacted with the subductionmetasomatized mantle wedge not only in the area of the mouth of Gulf of California, but further SE, below SPC graben area, which represents the transition zone between the area of coexistence of calc-alkaline and Na-alkaline magmatism in the NW and the SE area, where only calc-alkaline magmatism is present.

\section{CONCLUSION}

New K-Ar ages along with published ones have allowed us to obtain a clearer picture of the magmatic activity in the San Pedro-Ceboruco graben, including the monogenetic volcanic activity and Tepetiltic volcano for which previous data were absent. Volcanic activity started at $\sim 2.5 \mathrm{Ma}$ along the southern border of the graben with monogenetic volcanism. At the same time, dome complex volcanic activity began to be emplaced at $\sim 2.3 \mathrm{Ma}$ (Gastil et al., 1979) in the central part of the graben, followed by a caldera collapse event that took place before $\sim 1.1 \mathrm{Ma}$. The activity continued with the emplacement of pericaldera lava flows (1.1 $\pm 0.3 \mathrm{Ma}$; Ferrari et al., 2000a) and several domes (intracaldera, pericaldera and lateral domes) ranging from $\sim 0.9$ to $0.1 \mathrm{Ma}$. Subsidence with consequent reactivation of the eastern caldera rim occurred after $\sim 0.6 \mathrm{Ma}$ following the emplacement of the huge intracaldera domes. The activity of monogenetic centers and of stratovolcanoes started at $\sim 0.5 \mathrm{Ma}$ in the northern 
border of the graben. Volcanism shifts from SW to NE along NW-SE trending lines that coincide with the main directions of regional faults. The peculiar magmatic activity, characterized by the coexistence of different petrologic affinities (subduction-related and intra-plate), is younger than $1 \mathrm{Ma}$.

Acknowledgments-The authors deeply thank L. Ferrari for discussion, logistic support and help during field work, S. Conticelli for helpful discussion and P. Manetti for supporting this research. The manuscript was considerably improved in focus and logic through reviews of M. Ban and an anonymous reviewer. A. Pietruszka is thanked for the revision of the English style. This study was financially supported by C.N.R. with a fellowship (No. 203.05.21 Cod. No. 23.05.21) to C.M.P. and with C.S.M.G.A. grants.

\section{REFERENCES}

Allan, J. F. (1986) Geology of northern Colima and Zacoalco grabens, southwest Mexico: Late Cenozoic rifting in the Mexican Volcanic Belt. Geol. Soc. Am. Bull. 97, 473-485.

Dalrymple, G. B. and Lanphere, M. A. (1969) Potassium-Argon Dating. Freeman and Company, San Francisco, 258 pp.

DeMets, C. and Traylen, S. (2000) Motion of the Rivera plate since 10 Ma relative to the Pacific and North America plates and the mantle. Tectonophysics $\mathbf{3 1 8}$, $119-159$.

Faure, G. (1986) Principle of Isotope Geology. John Wiley \& Sons, 589 pp.

Ferrari, L. (1995) Miocene shearing along the northern boundary of the Jalisco block and the opening of the Southern Gulf of California. Geology 23, 751754.

Ferrari, L. and Rosas-Elguera, J. (2000) Late Miocene to Quaternary extension at the northern boundary of the Jalisco block, western Mexico: the TepicZacoalco rift revised. Geol. Soc. Am. Sp. Paper 334, Chapter 03, 41-64.

Ferrari, L., Nelson, S. A., Rosas-Elguera, J., AguirreDiaz, G. J. and Venegas-Salgado, S. (1997) Tectonics and volcanism of the Western Mexican Volcanic Belt. Magmatism and tectonics in central and northwestern Mexico-a selection of the 1997. IAVCEI General Assembly Excursions (Aguirre-Diaz, G. J., Aranda-Gomez, J. J., Carrasco-Nuñez, G. and Ferrari, L., eds.), Excursion 12, 85-129, Mexico D.F., Universidad Nacional Autonoma de Mexico, Instituto de Geologia.

Ferrari, L., Pasquarè, G., Venegas-Salgado, S. and Romero-Rios, F. (2000a) Geology of the western Mexican Volcanic Belt and adjacent Sierra Madre Occidental and Jalisco block. Geol. Soc. Am. Sp. Paper 334, Chapter 04, 65-84.

Ferrari, L., Petrone, C. M. and Francalanci, L. (2000b) Generation of OIB-type volcanism in the western Trans-Mexican Volcanic Belt by slab rollback, astenosphere infiltration and variable flux-melting. Geology (submitted).

Ferrari, L., Conticelli, S., Vaggelli, G., Petrone, C. M. and Manetti, P. (2000c) Late Miocene volcanism and intra-arc tectonics during the early development of the Trans-Mexican Volcanic Belt. Tectonophysics 318, 161-185.

Franzini, M., Leoni, L. and Saitta, M. (1972) A simple method to valutate the matrix effect in $x$-ray flourescence analysis. X-ray Spectrometry 1, 151154.

Gastil, G., Krummenacher, D. and Minch, J. (1979) The record of Cenozoic volcanism around the Gulf of California. Geol. Soc. Am. Bull. 90, Part 1, 839-857.

Itaya, T. and Nagao, K. (1988) K-Ar age determination of volcanic rocks younger than $1 \mathrm{Ma}$. Mem. Soc. Geol. Japan 29, 143-161 (in Japanese with English abstract).

Luhr, J. F. (2000) The geology and petrology of Volcan San Juan (Nayarit, Mexico) and the compositionally zoned Tepic Pumice. J. Volcanol. Geotherm. Res. 95, 109-156.

Mahood, G. A. and Drake, R. E. (1982) K-Ar dating young rhyolitic rocks: a case study of the Sierra $\mathrm{La}$ Primavera, Jalisco, Mexico. Geol. Soc. Am. Bull. 93, 1232-1241.

Matsumoto, A. (1989) Improvement for determination of potassium in K-Ar dating. Bull. Soc. Geol. Surv. Japan 40, 65-70 (in Japanese with English abstract).

Matsumoto, A. and Kobayashi, T. (1995) K-Ar age determination of late Quaternary volcanic rocks using the "mass fractionation correction procedure": application to the Younger Ontake Volcano, Central Japan. Chem. Geol. 125, 123-135.

Matsumoto, A., Uto, K. and Shibata, K. (1989) K-Ar dating by peak comparison method: new technique applicable to rocks younger than 0.5 Ma. Bull. Geol. Surv. Japan 40, 565-579.

Nelson, S. A. (1980) Geology and petrology of Volcan Ceboruco, Nayarit, Mexico. Geol. Soc. Am. Bull. Part II 91, 2290-2431.

Nelson, S. A. and Carmichael, I. S. E. (1984) Pleistocene to recent alkalic volcanism in the region of Sanganguey volcano, Nayarit, Mexico. Contrib. Mineral. Petrol. 85, 321-335. 
Nelson, S. A. and Hegre, J. (1990) Volcan Las Navajas, a Pliocene-Pleistocene trachyte-peralkaline rhyolite volcano in the northwestern Mexican Volcanic Belt. Bull. Volcanol. 52, 186-204.

Nelson, S. A. and Livieres, R. A. (1986) Contemporaneous calc-alkaline and alkaline volcanism at Sanganguey volcano, Nayarit, Mexico. Geol. Soc. Am. Bull. 97, 798-808.

Petrone, C. M. (1998) Studio magmatologico dei sistemi vulcanici del graben San Pedro-Ceboruco (Nayarit, Messico): coesistenza di magmi a diversa affinità petrologica. Ph.D. Thesis, Università degli Studi di Firenze, Italy, 280 pp. (in Italian).

Righter, K., Carmichael, I. S. E., Becker, T. A. and Renne, P. R. (1995) Pliocene-Quaternary volcanism and faulting at the intersection of the Gulf of California and the Mexican Volcanic Belt. Geol. Soc. Am. Bull. 107, No. 6, 612-626.

Rosas-Elguera, J., Ferrari, L., Garduño-Monroy, V. H. and Urrutia-Fucugauchi, J. (1996) Continental boundaries of the Jalisco block and their influence in the Pliocene-Quaternary kinematics of western Mexico. Geology 24, No. 10, 921-924.
Sudo, M., Tagami, T., Sato, K., Hasebe, N. and Nishimura, S. (1996) Calibration of a new Ar analytical system for the K-Ar dating method and analytical results of K-Ar age known samples. Mem. Fac. Science Geol., Mineral. Series, Kyoto Univ. LVIII, No. 1-2, 21-40.

Sudo, M., Uto, K., Anno, K., Ishizuka, O. and Uchiumi, S. (1998) SORI93 biotite: a new mineral standard for K-Ar dating. Geochem. J. 32, 49-58.

Takaoka, N. (1989) Problems in the K-Ar dating of Quaternary volcanic rocks younger than 1 Ma. Mass. Spectr. 37, 343-351 (in Japanese with English abstract).

Takaoka, N., Konno, K., Oba, Y. and Konda, T. (1989) $\mathrm{K}$-Ar dating of lavas from Zao Volcano, Northeastern Japan. J. Geol. Soc. Japan 95, 157-170 (in Japanese with English abstract).

Wallace, P. J. and Carmichael, I. S. E. (1994) Petrology of Volcan Tequila, Jalisco, Mexico: disequilibrium phenocryst assemblages and evolution of the subvulcanic magma system. Contrib. Mineral. Petrol. 117, 345-361. 